\title{
International Accounting Standards Effects on Business Management
}

\author{
Dr. Jeno Beke \\ Dept. of Accounting, Corporate Economics and Finance, Institute of Business and \\ Management, Faculty of Business and Economics, University of Pecs \\ No.58, Street of Magaslati, City of Pecs, Hungary, Europe \\ Tel: $36-72-313-681$ \\ E-mail: bekej@ktk.pte.hu
}

\begin{abstract}
Business strategy must be supported by appropriate organizational factors such as accounting information systems. Managers of businesses use accounting information to set goals for their organization. The fundamental purpose of management accounting is to help an organization achieve its strategic objectives. International management accounting is the practical application of management techniques to control and report on the financial resources of the business entities. With increasing globalization of the marketplace, international investors need access to financial information based on harmonized accounting methods and procedures. This study examines the impact of the adoption of international accounting standards on the management performance of businesses. The purpose of this study was the measuring the differences between the national rules and the international methods, the valuing and analyzing their effects on the business decisions. The result of this scientific research showed that the management performance indexes deteriorated especially regarding solvency and prosperity after adaptation of IFRS in the examined companies' case. The practical results showed an unpleasant picture regarding solvency and profitability at the examined companies. The IFRS adaptation had an influence on decreasing income of business managers. The author can advise for international management researchers to employ these methods and measure their effects on practical management functions.
\end{abstract}

Keywords: Business strategy, Management accounting system, Economics of accounting standards, Management performance effects, Management earnings, Hungary 


\section{Introduction}

In today's business environment, companies need to take every advantage they can to remain competitive. Global competition, rapid innovation, entrepreneurial competitors, and increasingly demanding customers have altered the nature of competition in the marketplace. This new competitive environment requires companies' ability to create value for their customers and to differentiate themselves from their competitors through the formulation of a clear business strategy. Business strategy must be supported by appropriate organizational factors such as effective manufacturing process, organizational design and accounting information systems too.

Modern business environments are increasingly competitive and dynamic. International competition through e-commerce and demand-based supply chain management dominate business. It is important for companies to develop coherent and consistent business strategies and to utilize management accounting tools to support strategic planning, decision-making and control. To integrate business strategies with various management accounting tools, first companies need to identify which business they are in. It is essential to identify products and services, customer types, geographical markets, and delivery channels. It is useful to match the strategic business unit (SBU) with the related business unit strategy. An SBU is a company department or sub-section which has a distinct external market for goods or services that differ from another SBU. A business unit strategy is about how to compete successfully in particular markets. It is important to focus on a certain segment, such as environmentally friendly cars in the automobile industry or internet and phone banking in the retail banking industry.

To be successful in this cut-throat competition business world is very tough particularly if you are not too familiar with the diverse strategies which are needed to make a business successful. If you cannot make a success story out of your business, there is no use of operating a business. You must have to undertake some strategies to run your business successful. These strategies are accounting, bookkeeping, marketing, promotion, production and manufacturing. Now what a business owner needs to do is prioritize work - what need to be done on priority basis. And this will vary greatly from business to business. Accounting help is something that any business requires to embark on, in particular if you are operating a large scale business. If you are running a small or mid-size business than you can easily handle the accounting work without obtaining professional assistance.

Generally, in a very large company, each division has a top accountant called the controller, and much of the management accounting that is done in these divisions comes under the leadership of the controller. On the other hand, the controller usually reports to the vice president of finance for the division who, in turn, reports to the division's president and/or overall chief financial officer (CFO). All of these individuals are responsible for the flow of good accounting information that supports the planning, control, and evaluation work that takes place within the organization.

Business management requires that resource consumption be measured, rated, assigned, and 
communicated between appropriate parties. Managers of businesses use accounting information to set goals for their organizations, to evaluate their progress toward those goals, and to take corrective action if necessary. Decisions based on accounting information may include which building and equipment to purchase, how much merchandise inventory to keep on hand, and how much cash to borrow, etc. Modern accounting renders its services to a wide variety of users: investors, government agencies, the public, and management of enterprises, to mention but a few. Many accountants work in business firms as managerial accountants, internal auditors, income tax specialists, systems experts, controllers, management consultants, financial vice presidents, and chief executives.

Accounting will help a business or organization to keep a proper record of all the financial aspect. Therefore, every individual or business requires keeping a track of all the financial dealings that they do on a daily basis. Because this is the only thing that will measure how well or how bad their business is doing. Many times it happens that the person managing the accounting and other financial aspect of the business does not make a habit to keep track on all the financial records on daily or weekly basis. Thus, business owner may not get the proper picture for their business - how good or how bad business is doing. This is true especially with small and mid-size businesses. It is very vital to have all the things well organized and documented, especially if you are of those who forget things.

Accounting is something that no one can avoid and therefore one must ensure that they get the best professionals to do the work for them. There are quite a lot of companies that offer accounting help with other bookkeeping and accounting services to individuals and business owners who are looking out for these services. If you have a glance at global accounting outsourcing statistics, you will notice that an increasingly large number of businesses are undertaking this strategy for their business success. Hence, if your name is yet to be in those statistics, it is a good time for you to seek accounting help for your business. There are number of advantages of outsourcing your accounting, and this is the cause why there is a vast flow in the number of business owners and entrepreneurs opening up to the idea of outsourcing their work.

To have strategic value, management accounting must help accomplish the three strategic objectives of quality, cost, and time by providing information that:

1. Links the daily actions of managers to the strategic objectives of an organization.

2. Enables managers to effectively involve the entire extended enterprise of customers, suppliers, dealers, and recyclers in achieving the strategic objectives.

3. Takes a long-term view of organizational strategies and actions.

The purpose of management accounting in the organization is to support competitive decision making by collecting, processing, and communicating information that helps management plan, control, and evaluate business processes and company strategy. The interesting thing about management accounting is that it is rare to find an individual within a company with the title of "management accountant." Often many individuals function as accountants within 
the organization, but these individuals typically operate as financial accountants, costs accountants, tax accountants, or internal auditors. However, the ability to develop and use good management accounting (which covers a lot more ground than the product costing done by cost accountants) is actually an important ability for many individuals, including finance professionals, operational and marketing managers, top-level executives, and information technologists.

The fundamental purpose of management accounting is to help an organization achieve its strategic objectives. Meeting these objectives satisfies the needs of its customers and other stakeholders. Typical stakeholders include shareholders, creditors, suppliers, employees, and labour unions. Corporations need to implement adequate internal controls, guidelines and policies to stay competitive and increase profit levels. Senior leaders rely on management accounting and strategy tools to review corporate processes and make short-term and long-term decisions.

The role of the management accountant is to perform a series of tasks to ensure their company's financial security, handling essentially all financial matters and thus helping to drive the business's overall management and strategy. A management accountant's responsibilities can range widely. Depending on the company, your level of experience, the time of year and the type of industry, you could find yourself doing anything from budgeting, handling taxes and managing assets to helping determine compensation and benefits packages and aiding in strategic planning.

International management accounting is the practical application of management techniques to control and report on the financial resources of the business entities. This involves the analysis, planning, implementation, and control of programs designed to provide financial reporting for managerial decision making. It is covering the maintenance of the accounts, developing financial statements, cash flow and financial performance analysis. Since accounting applications do not have uniform security and reliability requirements, it is not possible to devise a single accounting protocol and set of security services that will meet all needs. Thus the goal of management accounting is to provide a set of tools that can be used to meet the requirements of each application. International management accounting requires that resource consumption be measured, rated, assigned, and communicated between appropriate parties. Especially the multinational companies spend enormous money for preparing and auditing their accounting reports according to the different national regulations. For these multinational companies the aspects of maximizing the profit is significantly more important than the consideration of national interest or the geographical position. Because of this there is a demand for creating such accounting systems which are evaluating the economic results equally.

With increasing globalization of the marketplace, international investors need access to financial information based on harmonized accounting methods and procedures. Investors constantly face economic choices that require a comparison of financial information. Without harmonization in the underlying methodology of financial reports, real economic differences 
cannot be separated from alternative accounting methods and procedures. Harmonization is used as a reconciliation of different points of view, which is more practical than uniformity, which may impose one country's accounting point of view on all others. Organizations, private or public, need information to coordinate its various investments in different sectors of the economy. With the growth of international business transactions by private and public entities, the need to coordinate different investment decisions has increased.

According to the business practice it is obvious that the usage of international accounting principles leads to a reduction of the information asymmetry between the owners and the managers. By this information asymmetry are growing the costs of equities and are less accurate the economical and financial forecasts. This requires the development and review of the national accounting rules, the separate validation of the tax and accounting regulation, the repeal of the subordinate role of accounting, issuing international standards with the help of practical and theoretical accounting experts.

International Financial Reporting Standards (IFRS) are accounting principles, methods ('standards') issued by the International Accounting Standards Board (IASB), an independent organisation based in London. They purport to be a set of standards that ideally would apply equally to financial reporting by public companies worldwide. Between 1973 and 2000, international standards were issued by IASB's predecessor organisation, the International Accounting Committee (IASC), a body established in 1973 by the professional accountancy bodies in Australia, Canada, France, Germany, Japan, Mexico, Netherlands, United Kingdom and Ireland, and the United States. During that period, the IASC's principles were described as 'International Accounting Standards' (IAS). Since April 2001, this rule-making function has been taken over by a newly-reconstituted IASB. From this time on the IASB describes its rules under the new label 'IFRS', though it continue to recognise (accept as legitimate) the prior rules (IAS) issued by the old standard-setter (IASC). The IASB is better-funded, better-staffed and more independent than its predecessor, the IASC. Nevertheless, there has been substantial continuity across time in its viewpoint and in its accounting standards.

Standardization is the process of developing and agreeing upon technical standards. The standard is a document that establishes uniform engineering or technical specifications, criteria, methods, processes, or practices. Some standards are mandatory while others are voluntary. Voluntary standards are available if one chooses to use them. Some are de facto standards meaning a norm or requirement which has an informal but dominant status. Some standards are de jure meaning formal legal requirements. Formal standards organizations such as the International Organization for Standardization or the American National Standards Institute are independent of the manufacturers of the goods for which they publish standards.

The objective of this study was the measuring the differences between the national rules and the international methods, the valuing and analyzing their effects on the business decisions. This study examines the periods before and after the official adoption of IFRS. My paper investigates whether IFRS adoption reduces the level of earnings management and enhances 
the value relevance of international methods-based accounting numbers, especially in business performances.

\section{Previous related literature review}

International accounting literature provides evidence that accounting quality has economic consequences, such as costs of capital (Leuz and Verrecchia, 2000), efficiency of capital allocation (Bushman and Piotroski, 2006) and international capital mobility (Guenther and Young, 2008). The accounting system is a complementary component of the country's overall institutional system (Ormrod et al., 2006) and is also determined by businesses' incentives for financial reporting. Li and Meeks (2006) provide the first investigation of the legal system's effect on a country's financial system.

The financial reporting quality include the tax system (Schleifer and Vishny,. 2003) ownership structure (Easton, 2006; Ball and Lakshmann, 2005), the political system (Radebaugh and Gray, 2007), capital structure (Daske et al., 2006) and capital market development (Botsari and Meeks, 2008). Therefore, controlling for these institutional and firm-level factors becomes an important task in the empirical research design too.

One study (Meeks and Swamm, 2009) characterises of accounting amounts for businesses that adopted international standards to a matched sample of companies that did not, and found that the former evidenced less earnings management, more timely loss recognition, and more value relevance of accounting amount than did the latter. They found, that international standards adopters had a higher frequency of large negative net income and generally exhibited higher accounting quality in the post-adoption period than they did in the pre-adoption period. The results suggested an improvement in accounting quality associated with using international standards.

Another study (Jermakowicz et al., 2007) found that first time mandatory adopters experience statistically significant increases in market liquidity and value after international standards reporting becomes mandatory. The effects were found to range in magnitude from $3 \%$ to $6 \%$ for market liquidity and from $2 \%$ to $4 \%$ for businesses by market capitalization to the value of its assets by their replacement value.

\section{Methodology and results}

This study examines the impact of the adoption of international accounting standards on the management performance of businesses listed on the Budapest Stock Exchange in Hungary. The research work also seeks to identify the financial attributes of enterprises that national rules employed by the requirements of the Hungarian Financial Ministry.

Finally, the paper investigates whether international accounting standards reduces the level of earnings management, business profit and increases the value relevance.

My research is based on a qualitative comparative approach. In order to identify the results of my scientific research about the evaluation of the accounting standards in Hungary I have 
elaborated the following hypotheses:

$\mathbf{H}_{1}$ : The Management performance indexes deteriorated especially regarding solvency and prosperity after adaptation of IFRS in the examined companies' case.

$\mathbf{H}_{2}$ : IFRS adoption reduced earnings management.

The purpose of this study was the measuring the differences between the national rules and the international methods, the valuing and analyzing their effects on the business decisions. This survey contains information on how local, national accounting rules differ from IFRS on incorporating recognition, measurement, and disclosure rules.

To analyze business adoption decision my sample consists of Budapest Exchange Trade (BET) companies who compulsory adopted international financial reporting standards in Hungary, from 2007. In this research the pre-adoption examination period is in year of 2006 and the post-adoption is in year of 2007. My final sample comprises 65 IFRS adopting and 260 local (Hungarian) accounting rules user firms. For the chosen of the national accounting rules user enterprises I introduced mathematic-statistic methods. An alternative approach it to create a matched sample of local rules businesses based on criteria such as year and industry. It is chosen to incorporate all local rules firms due to methodological concerns about the matched-pairs research design. Financial data are from published accounting statements in BET and Hungarian Business Information database. In my sample the businesses are classified into those following IFRS and those following national accounting rules.

\subsection{Accounting methods and management performance effects}

This set of analyses measures how Hungarian enterprises have been affected on management performance by IFRS. The logistic regression models employed are as follows $(1,2)$ :

$$
\begin{aligned}
& R R_{i, t}=a_{0}+a_{1} \text { Size }_{i, t}+a_{2} \text { Dividend }_{i, t}+a_{3} \text { Growth }_{i, t}+a_{4} \text { Profitability }_{i, t}+ \\
& +a_{5} \text { Liquidity }_{i, t}+a_{6} \text { Leverage }_{i, t}+e i_{, t} .
\end{aligned}
$$

$$
\begin{gathered}
\text { PA }_{i, t}=a_{0}+a_{1} \text { Size }_{i, t}+a_{2} \text { Dividend }_{i, t}+a_{3} \text { Growth }_{i, t}+a_{4} \text { Profitability }_{i, t}+ \\
+a_{5} \text { Liquidity }_{i, t}+a_{6} \text { Leverage }_{i, t}+e i_{, t}
\end{gathered}
$$

Where:

$R R_{i, t}=$ dummy variable, indicating the regulatory system,

$R R_{i, t} \quad=1$, financial numbers are reported under IFRS,

$R R_{i, t} \quad=0$, financial numbers are reported under National GAAP,

$P A_{i, t} \quad=$ dummy variable, indicating the post-adoption effects.

$P A_{i, t} \quad=1$, financial numbers are reported under IFRS in 2007

$P A_{i, t} \quad=0$, financial numbers are reported under IFRS in 2006

Size: Natural logarithm of market capitalization:
- NAVSH:
Net asset value per share 
- RESSFU: Reserves to shareholders'funds

Dividend:

- DIVCOV: Dividend cover

- DIVSH: $\quad$ Dividend per share

- DIVYI: Dividend yield.

Growth:

- MVBV: $\quad$ Market value to book value

Profitability:

- EPS: $\quad$ Earnings per share

- NPM: $\quad$ Net profit margin

- ROCE: $\quad$ Return on capital employed

Liquidity:

- CFM:

Cash flow margin

- CUR:

Current ratio

- OCF:

Operating cash flow scaled by total assets

- QUI:

Quick ratio

- WCR:

Working capital ratio

Leverage:

- DEBTE: Debt to equity

- DSFU: Debt to shareholders'funds

- CGEAR: Capital gearing

$e_{i, t} \quad=$ the error term

The results are reported in table 1.

Table 1. Management performance effects

\begin{tabular}{|c|c|c|c|c|}
\hline \multirow{2}{*}{ Denomination } & \multicolumn{2}{|c|}{ National GAAP employed enterprises } & \multicolumn{2}{c|}{ IFRS adopter enterprises } \\
\cline { 2 - 5 } & Mean & Std. deviation & Mean & Std. deviation \\
\hline DIVSH & 0,0846 & 0,1986 & 0,1557 & 0,2106 \\
DIVYI & 17,5764 & 19,8721 & 22,8705 & 25,4457 \\
MVBV & 5,8152 & 7,8125 & 2,5478 & 8,1547 \\
NPM & $-0,2945$ & 4,5412 & $-0,1031$ & 7,4581 \\
EPS & 0,1987 & 1,0561 & 0,1897 & 1,5061 \\
ROCE & 0,2008 & 0,3051 & $-0,0081$ & 0,6401 \\
OCF & 3,8812 & 15,4421 & 4,8512 & 16,8041 \\
CUR & 1,9911 & 6,9105 & 2,9814 & 3,1125 \\
CFM & 0,8029 & 2,3126 & $-0,0408$ & 1,5974 \\
DEBTE & 1,9843 & 2,3566 & 2,3099 & 2,1577 \\
CGEAR & 0,3454 & 0,2325 & 0,8714 & 0,3115 \\
DSFU & 0,3258 & 0,1353 & 0,5469 & 0,8540 \\
\hline
\end{tabular}

(Source: Author's own constructions) 
It is provable by the table 1 that the average index of dividend, share (coming from earnings after tax) is more prosperous at companies which already adapted the international financial reporting standards (IFRS) than in case of others. However, the relative average value (DIVYI) contains a high deviation (the deviation value is almost 30 in case of companies operating with IFRS).

The companies applying the national accounting standards are gaining more than double $(5,8152)$ in terms of growth, measured by market value of assets to historical value of assets, respect to other enterprises. In this sense the IFRS user companies' average index is much lower.

The monitored enterprises had a negative average net profit value (loss) in both group in the covered period. However the return on equity and the average return on capital employed give better results in case of national accounting standards users. The latter index showed a declining tendency $(-0,0081)$ at companies which adapted the IFRS.

The examined national accounting standard user companies' average indexes, measuring solvency (OCF, CUR, CFM) and leverage were more prosperous than the other ones'. The Cash Flow, for instance, decreased $(-0,0408)$ at IFRS user companies, though around the relative average value of Operating Cash Flow on assets the deviation is quite high (it is between 15 and 17). As the indebtedness of companies accounting according to national regulation was lower, the leverage indexes (DEBTE, CGEAR, DSFU) were better than the other companies which adapted IFRS.

To sum up, it can be stated that the management performance indexes deteriorated especially regarding solvency and prosperity after adaptation of IFRS in the examined companies' case.

\subsection{Accounting methods and earnings management}

The first earnings management test measured the volatility of the change in net profit scaled by total assets, $\triangle \mathrm{NP}$, and the volatility of the change in net profit to the change in operating cash flows, $\triangle \mathrm{CF}$ for the national GAAP employed and the IFRS adopted enterprises.

The second earnings management test examined the associations between accruals and cash flows. My scientific research evaluated the Pearson correlation between accruals and cash flows separately in the pre-official, official and post-official adoption periods. Then the author employed an Ordinary Least Square (OLS) regression, followed Iatridis,G. and Rouvolis,S. (2010) researches, to analyse the associations between accruals and cash flows, profitability, leverage and size. The regression model that is used is as follows (3):

$$
\begin{gathered}
\operatorname{ACCR}_{i, t}=a_{0}+a_{1} \text { FRS }_{i, t}+a_{2} \text { FRSOCF }_{i, t}+a_{3} \text { FRSLNMV }_{i, t}+a_{4} \text { FRSOPM }_{i, t}+ \\
+a_{5} \text { FRSTLSFU }_{i, t}+e_{i, t}
\end{gathered}
$$

Where:

ACCRi,t $\quad=$ Accruals scaled by total assets.

FRSi,t $\quad=$ Dummy variable indicating the financial reporting system in use. FRSi, $t=1$ for firms reporting under IFRS in 2007, 
FRSi,t $=0$ for firms reporting under the National GAAP in 2006.

OCF $=$ Multiplication of IFRS and operating cash flows.

FRSOCFi,t $=$ Variable used to examine the impact of IFRS on the association between accruals and cash flows.

LNMV $=$ Multiplication of IFRS and the natural logarithm of market value.

FRSLNMVi,t $=$ Variable used to examine the impact of IFRS on the association between accruals and size.

OPM = Multiplication of IFRS and operating profits margin.

FRSOPMi,t $=$ Variable used to examine the impact of IFRS on the association between accruals and profitability.

TLSFU = Multiplication of IFRS and total liabilities to shareholders'funds.

FRSTLSFUi,t $=$ Variable used to examine the impact of IFRS on the association between accruals and leverage.

The results of the previous regression model (3) the author summarized in table 2.

Table 2 . Accounting methods and earnings management

\begin{tabular}{|c|c|c|}
\hline Denomination & National GAAP followed enterprises & IFRS adopter enterprises \\
\hline$\Delta \mathrm{NP}$ volatility & 4,1581 & 6,1021 \\
\hline$\Delta \mathrm{NP} / \Delta \mathrm{CF}$ volatility & 11,4401 & 12,0120 \\
\hline FRSOCF & $-1,21 * *$ & $-0,7145 * *$ \\
\hline FRSLNMV & $-0,025 * *$ & $-0,014 *$ \\
\hline FRSOPM & $0,5541 * *$ & $0,2145^{* *}$ \\
\hline FRSTLSFU & $-0,2574 * *$ & $-0,1941 * *$ \\
\hline $\mathrm{R}^{2}$ & 0,784 & 0,815 \\
\hline
\end{tabular}

(Source: Author's own construction)

According to the results of the table it can be stated that the companies which adapted IFRS reached a higher volatility in Net Profit value change $(\Delta \mathrm{NP})$ and in Net Profit value change/Operating Cash Flow value change $(\Delta \mathrm{NP} / \Delta \mathrm{CF})$. Being so, the volatility did not decline after the standard adaptation, contrary to the companies using national accounting standards.

The coefficient of correlation between deferred items, namely Accrued Charges and Cash 
Flow (FRSOCF) had a negative value in a significance level of $5 \%$ in both group, even so, the leaders of the national accounting principle user companies gained higher income $(-1,21)$.

The coefficient showing correlation between deferred items (accruals) and size of the company (FRSLNMV) was also negative: $(-0,025)$ in a significance level of $10 \%,(-0,014)$ in a significance level of 5\%; accordingly even the bigger companies using IAS/IFRS could not insert totally the principles of accounting accruals in their system yet.

Similarly, the companies which already adapted IFRS did not increase their Accrued Charges as a consequence of high indebtedness, which is showed by the coefficient of correlation between deferred items (accruals) and leverage (FRSTLSFU) being $(-0,1941)$.

The coefficient of correlation between deferred items and profitability (FRSOPM) is significantly positive in both groups of companies. However, it is worthy of note that the companies achieving lower profitability are less willing to adapt accrual principles into their accounting policy.

As a conclusion, it is my conviction that the practical results for instance, in case of FRSOCF, have proven my assumption that the income level of concerned leaders of companies which adapted the IFRS is decreased in a significance level of $5 \%$.

\section{Conclusion}

My study scrutinized the consequences of the IFRS adoption. The practical results showed an unpleasant picture regarding solvency and profitability at the examined companies.

My analyses have proven that the internal efficiency measured by accounting indicators of the concerned companies depended on their financial situation, their capitalization also after IFRS adaptation. As stated before, the IFRS adaptation had an influence on decreasing income of leaders/managers too.

According to the previously quoted studies and researches, the reported accounting results after IFRS adaptation are no more flexibly changeable and as a consequence of cost-benefit accounting, they are transparent too. Being so, the IFRS are becoming one of the most efficient tools for internal performance measurement and evaluation.

I have examined the practical realization of the assumptions supposed, through accounting data of national companies (in the sample) and I found that - except for some case - the results were in correlation with my previous statements.

As a consequence of the IFRS adaptation the policy and requirements became gradually more transparent and bright, so as became the application of the standards and the implementation process more user friendly.

The author can advise for international management researchers to employ these methods and measure their effects on practical management functions. 


\section{References}

Ball,R., Laksmann,S. (2005). Earnings quality in UK private firms. Journal of Accounting and Economics, 39, 83-128.

Botsari, A., Meeks, G. (2008). Do acquirers manage earnings prior to share for share bid? Journal of Business Finance and Accounting, 35, 633-670.

Bushmann,R., Piotroski, J. (2006). Financial reporting incentives for conservative accounting: the influence of legal and political institutions. International Journal of Business and Management, 27, 148-161.

Daske,H., Hail. L., Leuz, C., Verdi, R. (2006). Mandatory IFRS on the economic Consequences. University of Chicago.

Easton, P. (2006). Use of forecasts of earnings to estimate and compare cost of capital across regimes. Journal of Business Finance \& Accounting Research, 23, 74-89.

Epstein, B.,J. (2009). The Economic Effects of IFRS Adoption. The CPA Journal, 3, 26-31.

Guenther,A., Young,P. (2008). Financial Reporting Environments at International Capital Mobility. Journal of Accounting Researches, 08: 41-57.

Iatridis,G., Rouvolis,S. 2010. The post-adoption effects of the implementation of International Financial Reporting Standards in Greece. Journal of international accounting, auditing and taxation, 19, 55-65.

Jermakovicz,K., Kinsey,P., Wulf,I. (2007). The Value Relevance of Accounting Income Reported by DAX-30, German Companies. Journal of International Financial Management \& Accounting, 18, 611-641

Leuz,C., Verrecchia,R.E. (2000). The economic consequences of increased disclosure. Journal of Accounting Research, 38, 91-124.

Li,K., Meeks,G. (2006). The impairment of purchased goodwill: effects on market value.

Working Paper. Institute of Chartered Accountants in England and Wales. Centre for Business Performance. p.239.

Meeks,G., Swann,P. (2009). Accounting standards and the economics of standards. Accounting and Business Research, 39, 191-210.

Ormrod, P., Taylor, P. (2006). A study of the impact of IFRS adoption has looked beyond the early adopters for evidence. Journal of Accounting, 12, 82-84.

Radebaugh, L., Gray, S. (2007). International Accounting and Multinational Enterprises. 4th Edition. London. p. 381.

Schleifer, A., Vishny, R. (2003). Stock market driven acquisitions. Journal of Financial Economics, 70, 295-311. 